\title{
A Thematic Review on Composition of Board of Directors (BOD) and Its Impact on Performance.
}

\author{
Dipti Dhungel \\ MBM 2017, Nepal Commerce Campus
}

\begin{abstract}
This thematic paper has been prepared to find out how the composition of Board of Directors makes impact on performance of firms. To find this impact, the articles published in international journals have been reviewed. In addition to this detailed study of the legislator, the provision regarding composition of BOD in Nepal was made as stated in BAFIA and Company Act. The Board of Directorsis the elected members among the shareholders who could best represent the interest of each and every member. Corporate boards are one of the, if not the most important, internal corporate governance mechanisms that monitor and advise management in fulfilling the mandate to protect shareholder interests.There is still much debate as to the relationship between firm performance and boards of directors, which are arguably the main component of corporate governance.The thematic review concludes that the relationship between BOD and performance was not found on the basis of existing literature reviewed. Thus, the study opened the ground for the researcher to test this empirically.
\end{abstract}

Keywords: composition of $B O D$, performance, independent director, corporate governance,

\section{Conceptual review}

Corporate governance refers to application of best management practices, compliance of law and adherence of ethical standard for effective management and distribution of wealth and discharge of social responsibility for sustainable development of stakeholders. It also refers as an effective management of relationship among shareholders, managers, board, employees, customers, creditors and community. One of the most important pillar of corporate governance is independence. The one who is sitting on top of the position must not be influence from others and should act independently.

Despite the proliferation of studies, there is still much debate as to the relationship between firm performance and boards of directors, which are arguably the 
main component of corporate governance. Corporate boards are one of the, if not the most important, internal corporate governance mechanisms that monitor and advise management in fulfilling the mandate to protect shareholder interests.

There is an argue that with respect to corporate board composition, therepresentation of outside independent directors on boards cannot add economic value to firms. The concept of public limited companies is universal. Public limited companies emerged in the mid-nineteenth century as a form of business ownership that enabled a greater potential to raise capital and to limitinvestors' risk to their respective equity investments. Historically publiclimited companies were controlled by their owners, either through directmanagement or through direct control of management by owners (Mintzberg,1984). However, as the size of limited companies grew, direct owner involvementwas no longer practical. With the increase and dispersion of ownership and thecessation of direct involvement in corporations' management, a profession ofmanagement emerged. Consequently, the ownershipcontrol of the modern corporation is vested in the hands of management leadingto a so-called managerial hegemony (Mintzberg, 1984). This creates an agencyproblem of aligning the interests of shareholders with that of management.To mitigate the agency problem, Rose (2005) argues that the corporateboard plays a key role in supervising management and aligning their interestswith the interests of shareholders.

The board is considered to be a primaryinternal corporate governance mechanism (Brennan, 2006), as the boardmonitors and supervises management, and gives management strategicguidelines. It may act to review and ratify management's proposals. A board works to enhance the firm performance and enact legally vestedresponsibilities and fiduciary duties (Zahra and Pearce II, 1989).

There is a lacuna of studies as to whether the composition of boards ofdirectors can meet these stated responsibilities in the same ways in differingmarket contexts and jurisdictions in which they operate.Corporate governance convention adopted from advance markets'codes and principles in fulfilling the role of a board require executive andnon-executive directors to work together. It is assumed that boards withoutnon-executive directors act as a rubber stamp, and are dominated by theChief Executive Officer (CEO), and are plagued with conflicts of interests. The wave of corporate scandals, for example, Enron, WorldComand HIH lead to the question as to what composition of board is best ableto monitor management.Enron, WorldCom and $\mathrm{HIH}$ management were all involved in questionableaccounting practices which were undetected by their respective board.

Although there exist several studies on corporate governance in less developed and emerging economies in the context of Nepal there are very few studies on corporate board practices and governance. This study attempts to investigate whether board composition in the form of outside independent directors as considered in advanced systems, can influence firmeconomic performance.

\section{Methodology}

This paper is completely based on the review of different international journals and articles. 


\section{Literature review}

Rhoades, et, al.(2000), concluded that corporate board composition has small positive relationship with financial performance. Further, they find that the correlation between board composition measures (inside or outside director) and financial performance measure (ROA, ROE, etc.) depends on the actual measures used to define them in the study. What may be needed is a contingency approach to identify contexts in which outsider- dominated or insider-dominated structures are more appropriate. Outside directors are not the only means of achieving owner- interested actions. Independent leadership structure (separating CEO and Chairman of the Board roles), direct owner monitoring either through the board or independent of it, and incentive alignment through compensation contracts are but some of the other ways to ensure owner-interested action.

Rashid, et, al. (2010),revealed that there is no significant relationship between board composition in the form of representation of outside independent directors and firm performance, implying that the outside independent directors cannot add potential economic value to the firm in Bangladesh. It is also revealed that the board size has a significant negative influence on firm performance under accounting based performance measures, implying that there are information asymmetries between outside independent and other directors.

Maria-Eleni, et, al. (2010), recent scandals in the financial sector have brought corporate governance at the forefront of academic and supervisory attention. Banks' versatile role in the economic system has caught regulatory and supervisory interest around the world in an effort to inspire high quality corporate governance standards. Board structure, in the sense of board size and composition, and its impact on corporate performance constitutes an indispensable and, at the same time, prevalent theme of the corporate governance discussion.

Van Ness, et, al.(2010), indicated that board size and heterogeneity of director expertise are positively related to revenue growth, whereas the ratio of directors with education expertise and the ratio of directors of finance expertise have a negative effect on this performance measure. The results showed that both $\mathrm{CEO} / \mathrm{COB}$ duality and average tenure of board of directors have a positive effect on return on asset growth. They found that board size is negatively related to the debt to asset ratio but negatively related to free cash flow-to-net income while heterogeneity of tenure of board members is positively related to this same performance measure. They found no significant impact of outside directors, gender, or average board age on financial performance.

Dogan\& YILDIZ (2013), revealed that the results of the accounting based performance indicators rate of return on assets (ROA) and return on equity ratio (ROE) with the board size of the banks are negative and highly significant.However on the contrary the results between Tobin'q (Q) which is used as a market based indicator and the board size are revealed negative and highly significant. the increase in the number of members of Board of Directors has a negative impact on the bank performance. Another finding of this study is negative and statistically significant results concerning the relationship of banks' risk indicators and personnel costs with banks' performances.

ISIK \&INCE(2016) found a significant and positive relationship between board 
size and bank performance. Specifically, this empirical result confirms that banks may improve their performance by increasing their board size. They also found that the percentage of outside directors on the board is negatively but insignificantly associated with bank performance. One possible reason for this result is that outside directors appointed to the board may lack specific knowledge regarding the banks and banking sector in Turkey. This study contributes empirical evidence to the little studied area of corporate governance matters in commercial banks in Turkey, an emerging market.

\section{Regulatory Provision}

\section{Company Act 2063}

Chapter (6) BOARD OF DIRECTORS

Section(86) Board of Directors and number of Directors: (1) The appointment and number of directors of a private company shall be as provided in its article of association.

(2) Every public company shall have a board of directors consisting of a minimum of three and a maximum of eleven directors.

(3) In forming the board of directors pursuant to Sub-section (2), at least one independent director, in the case of the number of directors not exceeding seven, and at least two independent directors, in the case of the number of directors exceeding seven, shall be appointed from amongst the persons who have the knowledge as prescribed in the articles of association of the company and gained knowledge and experience in the subject related with the business of the company concerned.

(4) Any one director selected by the directors from amongst themselves shall be the chairperson of the board of directors.

Section(87) Appointment of directors: (1) The directors of a company shall be appointed by the general meeting of the company, subject to the provisions contained in Section 89 and the articles of association.

\section{Banks and Financial Institutions Act, 2063}

Chapter (3) Provisions Concerning Board of Directors and Chief Executive of Banks or Financial Institutions

Section (12) Formation of Board of Directors: (1) Every bank or financial institution shall have a Board of Directors. The Board shall consist of not less than five and not more than nine Directors.

(2) Subject to Sub-section (19, there shall be appointed to the board a professional director from the list of professional experts maintained by the Rastra Bank pursuant to Section 13. The director to be so appointed shall not be required to have subscribed any share of the concerned bank or financial institution.

(3) A director chosen by the directors from among themselves by a majority decision shall be the chairperson of the Board of Directors.

From the above literature reviewwhat we can find that the researchers mainly 
focused on single variable .i.e. only board size while measuring impact of composition of board of directors on performance. Whereas some researchers have also considered variables like independence of board of directors, age of a firm, tenure of directors, CEO duality. But the other variables like public firm, academic or experience expertise of directors and also the legal provisions have not been considered by above researchers. So, further research will be conducted taking these above mentioned variables.

\section{Conclusion}

The study showed that there is no significant relationship between board composition and firm performance. The financial performance of the firm is not related with the composition of Board of Directors although Board of Director is the governing body of any company.

Moreover, properly structuring the board of directors could be one of the most important pieces of determining the success for any venture. These are the people the company is going to be relying on for strategic direction, or voting on all key decisions. Whenever it comes to board of directors the central issue is corporate governance. BOD is linked with corporate governance directly. The board should consists such directors who could better represent the interests of every shareholders and stakeholders.

Although independent outside directors, in general, do play an advisory role rather than adding economic value, there is a need for further exploration as to whether independent directors can provide effective judgmental contributions to firms.

\section{Bibliography}

Agoraki, M. K., Delis, D. M., \& Staikouras K, P. (2010). The Effect of Board Size and Composition on Bank Efficiency. Journal of Accounting and Economics, 315-342.

Bernnan, N. (2006). Board of Directors and Firm Performance: Is There an Expectation Gap? Corporate Governance: An International Review, 577-593.

Dogan, \& YILDIZ. (2013). The impact of Board of Directors`Size on Bank's performance:evidence from turkey. european journal of business and management, 2222-2839.

Fama, E. F. (1980). agency problem and the theory of the firm. journal of political economy, 288308.

ISIK, \& INCE. (2016). Board SiZe,Board Composition and Performance. International Business Research, 9012-1913.

Mintzberg, H. (1984). Who Should Control The Corporation? California Management Review, 90116.

Rashid, A. D. (2010). Board composition and Firm Performance:Evidence from Bangladesh. australasian accounting, business nad finance journal, 76-95.

Rhoades, L. D., Rechner, L. P., \& Sundaramurthy, C. (2000). board composition and financial performance:a meta analysis of the influence of outside directors. journal of managerial issues, 76-91.

Rose, C. (2005). the composition of semi-two tier corporate boards and firm performance,corporate governance. an international review, 691-701.

Van Ness, K. R., Miesing, P., \& Kang, J. (2010). Board of Director Composition and Financial 
Performance in aSsarbanes Oxley World. academy of business and economics journal, 56-74. Zahra, S. A., \& Pearce II, J. A. (1989). Board of Directors and Corporate Financial Performance: A Review and Integrative Model. Journal of Management, 291-334. 